\title{
DOES ARTIFICIAL SNOW FERTILISE THE SOIL OF MOUNTAIN MEADOWS IN THE KRKONOŠE NATIONAL PARK?
}

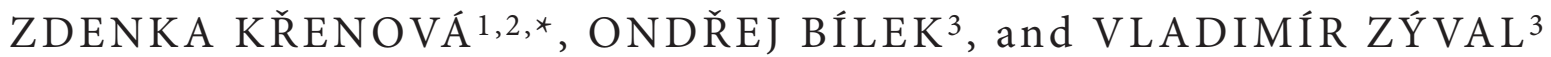 \\ ${ }^{1}$ Global Change Research Institute of the Czech Academy of Sciences, Bělidla 4a, CZ-60200 Brno, Czech Republic \\ ${ }^{2}$ Institute for Environmental Studies, Faculty of Science, Charles University, Benátská 2, CZ-12900 Prague, Czech Republic \\ ${ }^{3}$ Geo Vision s.r.o., Brojova 2113/16, 32600 Plzeň 2 - Slovany, Czech Republic \\ *Corresponding author: krenova.z@czechglobe.cz
}

\begin{abstract}
There are no high mountains in the Czech Republic and only few of them are higher than $1500 \mathrm{~m}$ a.s.l. Nevertheless, skiing is one of the most popular winter sports in this country and has a long history and tradition. During the last two decades, climate change, big differences in snow cover from year to year and unusual warm winter periods causing the snow to melt resulted in visitors to Czech ski resorts going to the Alps. Managers of ski resorts facing this challenge recognised that artificial snow enables skiing throughout the entire season and overcomes the risk posed by climate to the skiing business. However, many ski resorts are located in protected areas and it is difficult to negotiate changes in the rules for preparing and applying artificial snow with conservationists, who are fearful of the negative effects of snowmaking on rare and protected species and habitats. This paper presents results of a case study conducted in the SkiResort ČERNÁ HORA - PEC in the Krkonoše National Park throughout the 2019 season. The seasonal changes in the water quality in two reservoirs and six creeks, from which water is used for making artificial snow, were determined in order to assess the risk of this snow adding fertiliser to the meadows on ski slopes. We found that the nutrients recorded in two reservoirs and six creeks were very low. Water quality parameters did not exceed the limits of permissible pollution of surface and drinking water. Several episodic increases in the parameters measured were recorded and the causes discussed. We did not measure the direct effects of artificial snow on grassland communities. However, the use of water from these reservoirs and creeks for snowmaking does not pose a significant risk in terms of adding fertiliser to the meadows on ski slopes. To eliminate these risks and unusual events, several management measures for improving the water regime in the area studied are proposed. To better understand the effect of artificial snow on mountain meadows, permanent plots and long-term monitoring of vegetation, soil invertebrates and soil chemistry are recommended.
\end{abstract}

Keywords: artificial water reservoirs; climate change; management of protected areas; snow-making; water resources

\section{Introduction}

Skiing is one of the most popular winter sports in the Czech Republic and has a long history and tradition; the first ski club was founded in 1887 by Josef Rössler-Orovský. In 1893, the first ski races took place at Jilemnice (Krkokonoše - Giant Mountain) and in 1903 the Association of Skiers in the Czech Kingdom was founded, which was the first ski association in the world (www .ahscr.cz). In recent decades, there has been a significant development in skiing techniques as well as an increased demand for skiing-related services. In spite of the much lower altitudes than in the Alps, there is a large number of ski resorts all over the Czech Republic (about 200 ski areas with a total of almost 800 ski lifts), all of them located between 900 and 1,450 $\mathrm{m}$ a.s.l. (only 3 ski areas are at over $1,300 \mathrm{~m}$ a.s.l.).

In the Czech Republic, as well as in many other Eastern European countries, skiing is popular (Vanat 2019), however, the numbers skiing has not increased to the extent predicted in the first decade of this century. Even though Poland, Slovakia and the Czech Republic modernised their resorts, attendance remained stagnant. Of course, there can be various socio-economic reasons for this (incl. quality and price of the services offered in ski resorts) or climate change affecting the amount and quality of snow can play a role. Climate change, big differences in snow cover from year to year and previously unusual warm winter periods causing snow to melt, results in skiers going to the Alps rather than Czech ski resorts. Obviously, the ski industry in the Czech Republic faces the same problems as most other ski resorts. Attendance at Czech ski resorts has been stagnant or even declining for several years (Vanat 2019). In winter 2018/19, when there was an abundance of natural snow, there was a 3\% improvement in attendance, which reached the highest recorded over the last 10 years (AHS 2019). However, winter 2019/2020 was not good in terms of the amount of snow and attendance at Czech ski resorts was very low. There is high probability that winter tourism will have to deal with the adverse effects of global warming more often (e.g., Koenig and Abegg 1997; Breiling and Charamza 1999; Elsasser and Bürki 2002).

Managers of ski resorts know that snowmaking enables skiing throughout the entire season and mitigates the risks of global warming to the ski business. However, many ski resorts are located in protected areas and there are strict rules about the preparation and application of artificial snow devised by conservationists who fear it will have negative effects on rare and protected species and habitats. Scientific knowledge and recommendations are essential for the appropriate management of ski resorts and mitigation of their negative effects on mountain ecosystems, especially in national parks and other protected areas. During the last two decades, many papers report the effects of skiing and artificial snow on vege- 
tation (e.g. Jones and Devarennes 1995; Kammer 2002; Wipf 2005; Kocková 2011; Zeidler et al. 2016), soil invertebrates or small mammals (Negro et al. 2009, 2010), birds (Zeitler and Glanzer 1998; Baines and Richardson 2007; Thiel et al. 2008), soil quality (e.g. Freppaz et al. 2013) and the water regime (e.g. Treml et al. 2012; Fuksa 2016; Hruška 2017).

There have been occasional studies on the ecological aspects of downhill skiing in the Krkonoše National Park since the 1970s. Štursa (2007) states that downhill skiing has resulted in a lot of ecological problems for the management of the Krkonoše National Park mainly in terms of: (1) permanent decrease in total forest area and serious negative effects on the ecological stability of forest habitats adjacent to downhill slopes, (2) soil erosion on deforested slopes, (3) permanent changes in the character of the landscape and (4) the biotechnological management of downhill slopes. Ten years later, a new review of the effect of skiing on the nature in the Krkonoše/Giant Mts (Czech Republic) was published (Flousek 2016), which describes the particular effects of different activities associated with the construction and maintenance of new ski areas, operation and modernisation of ski areas and winter sports. He also considers the predicted effects of climate change on the future of the ski industry in mountain areas and discusses the increasing use of artificial snow. Hruška (2017) monitored the quality of water in the Labská Dam (17 km NW from our study area) as a potential source for the production of artificial snow in ski resorts in the Špindlerův Mlýn region and reports very low concentrations of nutrients in the water. In addition, Hruška et al. (2017) report that using water from this dam for making artificial snow results in the critical load for nitrogen deposition being exceeded at all the localities monitored. However, currently it is lower than it was in the 1990s, because between 2000 and 2016 atmospheric nitrogen deposition in the Krkonoše Mountains decreased by $22 \%$. This roughly corresponds to the increase that is likely to result from using water from the Labská Dam for artificial snow. Finally, possible effects of the high concentrations of $\mathrm{Ca}$ and $\mathrm{Mg}$ in artificial snow produced using water from this dam on acidified forest and grassland habitats are discussed by Hruška (2017).

Currently, there is an active research project of the Technology Agency of the Czech Republic No. TH02030080 entitled 'Support of long-term planning in the area of water management in the Krkonoše National Park. The first results of this project dealing with the effect of artificial snow on selected streams in terms of changes in flow rates and differences between natural snow and the snow lying on the slope in terms of snow density and associated runoff characteristics have been published by Treml (2019). He reports that water abstraction from medium and large streams for snowmaking does not pose a serious problem during a normal winter. Small streams are more vulnerable due to their greater fluctuations in flow rate. In winter there are two critical periods - the beginning of winter and periods of severe frost. To overcome this, he recommends the use of artificial reservoirs that are filled when flow rates are high.

Our study focused on the quality of the water in the artificial reservoirs used for snowmaking at the Ski Resort ČERNÁ HORA - PEC in terms of the seasonal variability in the quality of the water. The results were used to suggest possible ways of avoiding adding fertiliser to the meadows on ski slopes when applying artificial snow.

\section{Methods}

\section{Study sites and sampling of water}

The Krkonoše National Park (KRNAP, established in May 1962, area $363.27 \mathrm{~km}^{2}$ ), is the oldest Czech national park. KRNAP is located in the Giant Mountains (Krkonoše in Czech; the highest Czech geomorphological complex with the highest summit - Sněžka peak: 1,603 $\mathrm{m}$ a.s.1.). For decades, this area has been a very popular destination for winter sports, especially downhill and cross-country skiing. There are about 170 kilometres of ski pistes (www.krkonose.eu), many of which use artificial snow. SkiResort ČERNÁ HORA - PEC is the largest resort in this region (Fig. 1). Annually, about 850,000 visitors enjoy more than $50 \mathrm{~km}$ of slopes with 6 cableways and 21 lifts (www.skiresort.cz). Thanks to artificial snow, the season usually lasts from the beginning of December to the middle of April (or at least the end of March). This resort uses water from several creeks, two reservoirs and the Úpa River for preparing artificial snow.

The monitoring of water quality in the two reservoirs, the water of which is used for the preparation of artificial snow for SkiResort ČERNÁ HORA - PEC, was carried out during 2019. In particular, the no-flow reservoir located at the upper cableway station Černá hora (designated as site S1, Fig. 2) and a flow through reservoir near the lower cableway station at Janské Lázně (site S2, Fig. 3) were studied. These reservoirs were monitored over 15-30 day periods during the 2019 season. Monitoring started on April 3, 2019 and ended on January 7, 2020, i.e. at the time of the highest annual occupancy of accommodation facilities and when the water in the reservoirs had been used several times for snowmaking.

To compare the water quality in the reservoirs, several selected creeks occurring in study area and used for artificial snow production (S3-S8 sites) were sampled and chemical analyses conducted. Detailed descriptions of the sites monitored, S1-S8, together with the dates sampled are given in Table 1.

Samples of surface water from reservoirs were collected using a sampler at a depth of about $0.5-1.0 \mathrm{~m}$ and from creeks samples were collected from a depth of up to $0.2 \mathrm{~m}$ below the surface. Simultaneously, the physicochemical parameters of the water $(\mathrm{pH}$, conductivity, surface water temperature) were measured using $\mathrm{pH}$ and conductivity meters Hanna HI98129. The OPR meter Hanna HI98120 


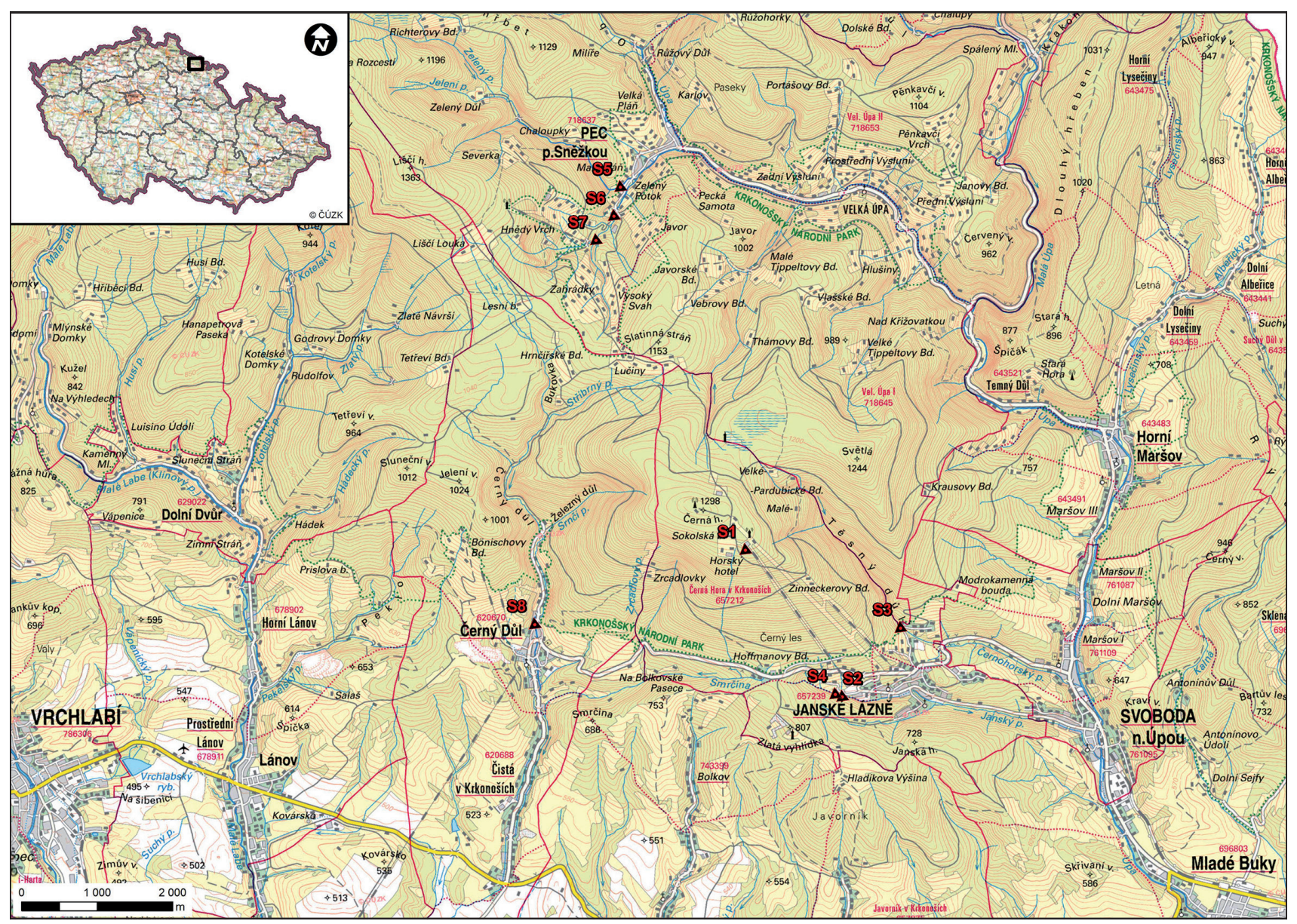

Fig. 1 Map of the study area.

was used to measure the redox potential - Eh. Both instruments were calibrated according to the manufacturer's instructions prior to measurement. After collection, the samples were stored in a portable refrigerated box and submitted for laboratory processing within a maximum of 36 hours.

\section{Chemical and data analyses}

Samples collected from the reservoirs and creeks were transferred to a certified laboratory - LABTECH Brno Ldt. - Hygienic Laboratories Klatovy. The following analyses were carried out according to the standard operat-

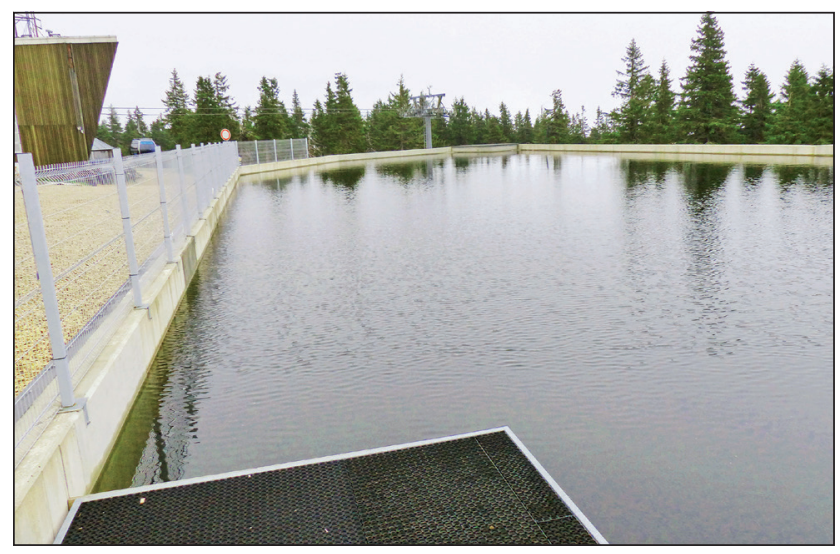

Fig. 2 The upper reservoir at study site S1. ing procedures of the accredited laboratory (accreditation of the Czech Accreditation Institute No. 1147) on all samples: $\mathrm{pH}$, conductivity, DOC, $\mathrm{P}_{\text {total }}, \mathrm{PO}_{4}{ }^{3-}, \mathrm{DON}$, $\mathrm{N}_{\text {total }}, \mathrm{NO}_{3}{ }^{-}, \mathrm{NH}_{4}{ }^{+}, \mathrm{Ca}$ and $\mathrm{Mg}$. Chlorophyll was determined only in samples from sites $\mathrm{S} 1$ and S2. All determined hydrochemical parameters are given in Table 2 .

We used the analysis of variation in STATISTICA 12 (Anonymous 2012) to compare the reservoirs and creeks. We also tested the effect of time and compared the quality of water in the reservoirs based on 13 samples using the Repeated Measurement in Split-plot ANOVA in the STATISTICA 12 program.

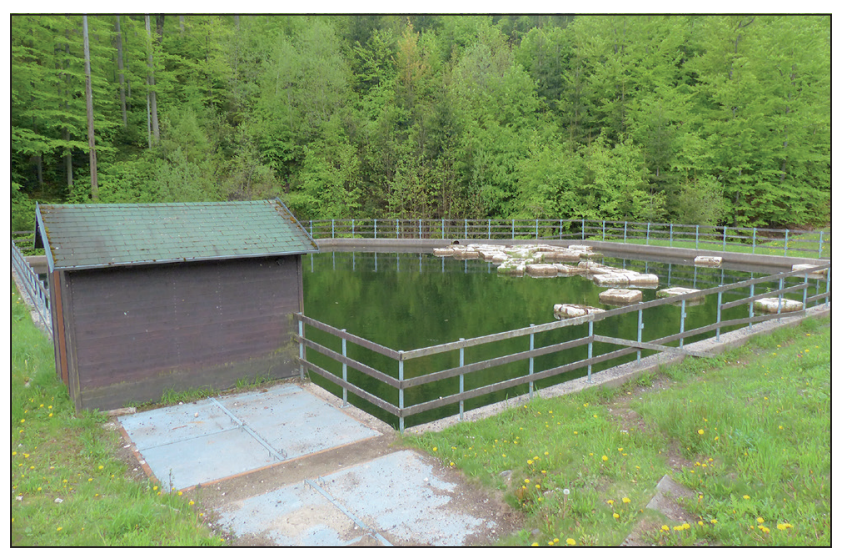

Fig. 3 The lower reservoir at study site S2.

European Journal of Environmental Sciences, Vol. 10, №. 1 
Table 1 Sites monitored and date sampled.

Sample sites S3-S8 were located where water is collected for making artificial snow: S3 - the upper reservoir; S4 - the lower reservoir (and partly also from the upper reservoir); S5 - ski slope Javor in Pec pod Sněžkou; S6 - ski slope Hnědý vrch; S7 - an alternative site for ski slope Hnědý vrch, a new reservoir is under consideration for this site; S8 - ski resort Černý Důl.

\begin{tabular}{|c|c|c|c|c|c|}
\hline & name & \multicolumn{2}{|c|}{ GPS coordinates $Y \mid X$} & site description & sampling* \\
\hline S1 & $\begin{array}{l}\text { Upper reservoir - } \\
\text { Černá hora }\end{array}$ & $50^{\circ} 38^{\prime} 51.753^{\prime \prime} \mathrm{N}$ & $15^{\circ} 45^{\prime} 4.057^{\prime \prime} \mathrm{E}$ & $\begin{array}{l}\text { An impermeable artificial reservoir (capacity } 10,790 \mathrm{~m}^{3} \text { ) } \\
\text { close to the upper station of cableway Janské Lázně - Černá } \\
\text { hora, } 1250 \mathrm{~m} \text { a.s.l. Built in } 2011 \text {. No fish. This reservoir is } \\
\text { filled from Černohorský Creek, which comes from the } \\
\text { Černohorské Peat Bogs and from the Janský Creek } \\
\text { (approximately in the ratio 2:1). }\end{array}$ & $\begin{array}{l}\mathrm{K} 01, \mathrm{~K} 02, \mathrm{~K} 03, \mathrm{~K} 04, \\
\mathrm{~K} 05, \mathrm{~K} 06, \mathrm{~K} 07, \mathrm{~K} 08, \\
\mathrm{~K} 09, \mathrm{~K} 10, \mathrm{~K} 11, \mathrm{~K} 12, \\
\mathrm{~K} 14\end{array}$ \\
\hline S2 & $\begin{array}{l}\text { Lower reservoir - } \\
\text { Janské Lázně }\end{array}$ & $50^{\circ} 37^{\prime} 48.548^{\prime \prime} \mathrm{N}$ & $15^{\circ} 46^{\prime} 8.349^{\prime \prime} \mathrm{E}$ & $\begin{array}{l}\text { An artificial reservoir (capacity } 2,060 \mathrm{~m}^{3} \text { ) close to the lower } \\
\text { station of cableway Janské Lázně - Černá hora, } 670 \mathrm{~m} \text { a.s.l. } \\
\text { Built in 2006. Population of brook trout lives in this reservoir. } \\
\text { This flow through reservoir gets water from Janský Creek. }\end{array}$ & $\begin{array}{l}\mathrm{K} 01, \mathrm{~K} 02, \mathrm{~K} 03, \mathrm{~K} 04, \\
\mathrm{~K} 05, \mathrm{~K} 06, \mathrm{~K} 07, \mathrm{~K} 08, \\
\mathrm{~K} 09, \mathrm{~K} 10, \mathrm{~K} 11, \mathrm{~K} 12, \\
\mathrm{~K} 14\end{array}$ \\
\hline S3 & $\begin{array}{l}\text { Černohorský } \\
\text { Creek - } \\
\text { Janské Lázně }\end{array}$ & $50^{\circ} 38^{\prime} 17.183^{\prime \prime} \mathrm{N}$ & $15^{\circ} 46^{\prime} 49.227^{\prime \prime} \mathrm{E}$ & $\begin{array}{c}\text { Springs from the Černohorské Peat Bogs. Samples were } \\
\text { collected along } 2.7 \text { km of this creek, on the outskirts of } \\
\text { Janské Lázně. }\end{array}$ & $\begin{array}{l}\mathrm{K} 01, \mathrm{~K} 02, \mathrm{~K} 03, \mathrm{~K} 04, \\
\mathrm{~K} 09, \mathrm{~K} 13, \mathrm{~K} 14\end{array}$ \\
\hline S4 & $\begin{array}{l}\text { Janský Creek - } \\
\text { Janské Lázně }\end{array}$ & $50^{\circ} 37^{\prime} 49.381^{\prime \prime} \mathrm{N}$ & $15^{\circ} 46^{\prime} 5.529^{\prime \prime} \mathrm{E}$ & $\begin{array}{l}\text { On the southern hillside of Černá hora. } \\
\text { Samples were collected along } 3.95 \mathrm{~km} \text { of this creek, } \\
\text { near the lower reservoir (S2). }\end{array}$ & $\begin{array}{l}\mathrm{K} 01, \mathrm{~K} 02, \mathrm{~K} 03, \mathrm{~K} 04, \\
\mathrm{~K} 09, \mathrm{~K} 13, \mathrm{~K} 14\end{array}$ \\
\hline S5 & $\begin{array}{l}\text { Zelený Creek - } \\
\text { Pec p. Sněžkou }\end{array}$ & $50^{\circ} 41^{\prime} 27.513^{\prime \prime} \mathrm{N}$ & $15^{\circ} 43^{\prime} 41.863^{\prime \prime} \mathrm{E}$ & $\begin{array}{l}\text { On the eastern hillside of Zadní Planina Mt. } \\
\text { Samples were collected along } 1.1 \mathrm{~km} \text { of this creek. }\end{array}$ & $\begin{array}{l}\mathrm{K} 01, \mathrm{~K} 02, \mathrm{~K} 03, \mathrm{~K} 04, \\
\mathrm{~K} 09, \mathrm{~K} 13, \mathrm{~K} 14\end{array}$ \\
\hline S6 & $\begin{array}{l}\text { Vlčí Creek } 1 \text { - } \\
\text { Pec p. Sněžkou }\end{array}$ & $50^{\circ} 41^{\prime} 14.519^{\prime \prime} \mathrm{N}$ & $15^{\circ} 43^{\prime} 37.296^{\prime \prime} \mathrm{E}$ & $\begin{array}{l}\text { On the south-eastern hillside of Liščí Mt. } \\
\text { Samples were collected along } 0.65 \mathrm{~km} \text { of this creek. }\end{array}$ & $\begin{array}{l}\mathrm{K} 01, \mathrm{~K} 02, \mathrm{~K} 03, \mathrm{~K} 04, \\
\mathrm{~K} 09, \mathrm{~K} 13, \mathrm{~K} 14\end{array}$ \\
\hline S7 & $\begin{array}{l}\text { Vlčí Creek } 2 \text { - } \\
\text { Pec p. Sněžkou }\end{array}$ & $50^{\circ} 41^{\prime} 4.266^{\prime \prime} \mathrm{N}$ & $15^{\circ} 43^{\prime} 24.849^{\prime \prime} \mathrm{E}$ & $\begin{array}{l}\text { On the south-eastern hillside of Lišči Mt. } \\
\text { Samples were collected along } 1.1 \mathrm{~km} \text { of this creek. }\end{array}$ & $\begin{array}{l}\mathrm{K} 01, \mathrm{~K} 02, \mathrm{~K} 03, \mathrm{~K} 04, \\
\mathrm{~K} 09, \mathrm{~K} 13, \mathrm{~K} 14\end{array}$ \\
\hline S8 & $\begin{array}{l}\text { Čistá Creek - } \\
\text { Černý Důl }\end{array}$ & $50^{\circ} 38^{\prime} 20.078^{\prime \prime} \mathrm{N}$ & $15^{\circ} 42^{\prime} 41.740^{\prime \prime} \mathrm{E}$ & $\begin{array}{l}\text { On the east-south hillside of Liščí Mt. } \\
\text { Samples were collected along } 15.9 \text { km of this creek, } \\
\text { in the outskirts of Černý Důl village. }\end{array}$ & $\begin{array}{l}\mathrm{K} 01, \mathrm{~K} 02, \mathrm{~K} 03, \mathrm{~K} 04, \\
\mathrm{~K} 09, \mathrm{~K} 13, \mathrm{~K} 14\end{array}$ \\
\hline \multicolumn{6}{|c|}{$\begin{array}{l}\text { *codes and dates when sampled: } \\
\text { KO1 - 3/4/2019; K02 -4/5/2019; K03 - 17/5/2019; K04-3/6/2019; K05 - 19/6/2019; K06 - 2/7/2019; K07-16/7/2019; } \\
\text { K08 - 7/8/2019; K09-22/8/2019; K10 - 3/9/2019; K11 - 29/9/2019; K12 - 30/10/2019; K13-4/12/2019; K14 - 6/1/2020 } \\
\text { Samples K13 were not collected from sites S1 and S2 because of lack of water due to artificial snow preparation at the beginning of the season. }\end{array}$} \\
\hline
\end{tabular}

Table 2 Water quality parameters recorded for samples collected from the upper (S1) and lower (S2) artificial reservoirs during 2019. Listed are basic statistical characteristics and limits of permissible pollution of surface and drinking water.

\begin{tabular}{|c|c|c|c|c|c|c|c|c|c|c|c|}
\hline \multirow{2}{*}{$\begin{array}{l}\text { parameters } \\
\text { site: }\end{array}$} & \multicolumn{2}{|c|}{ average } & \multicolumn{2}{|c|}{ median } & \multicolumn{2}{|c|}{$\min$} & \multicolumn{2}{|c|}{$\max$} & \multirow{2}{*}{$\begin{array}{l}\text { permissible } \\
\text { pollution } \\
\text { of surface } \\
\text { water }{ }^{\text {a) }}\end{array}$} & \multirow{2}{*}{$\begin{array}{l}\text { permissible pol- } \\
\text { lution of surface } \\
\text { water used for } \\
\text { supplying waterb) }\end{array}$} & \multirow{2}{*}{$\begin{array}{l}\text { permissible } \\
\text { pollution } \\
\text { of drinking } \\
\text { waterc) }\end{array}$} \\
\hline & S1 & S2 & S1 & S2 & S1 & S2 & S1 & S2 & & & \\
\hline $\mathrm{pH}$ & 7.35 & 7.36 & 7.49 & 7.18 & 6.37 & 6.72 & 8.56 & 8.97 & $5-9$ & & $6.5-9.5$ \\
\hline conductivity [mS/m] & 5.02 & 7.93 & 4.89 & 7.91 & 4.23 & 5.52 & 6.51 & 10.80 & & & 125 \\
\hline $\mathrm{NH}_{4}^{+}[\mathrm{mg} / \mathrm{l}]$ & 0.03 & 0.11 & 0.02 & 0.05 & $<0.02$ & $<0.02$ & 0.13 & 0.32 & 0.23 & & 0.5 \\
\hline $\mathrm{NO}_{3}{ }^{-}[\mathrm{mg} / \mathrm{l}]$ & 0.68 & 2.03 & 0.25 & 2.20 & $<0.50$ & $<0.50$ & 1.55 & 4.20 & 5.4 & & 50 \\
\hline $\mathrm{N}$ total $[\mathrm{mg} / \mathrm{l}]$ & 0.59 & 1.20 & 0.40 & 1.01 & 0.10 & $<0.50$ & 2.14 & 4.74 & 6 & & \\
\hline DON - N organic [mg/l] & 0.36 & 0.65 & 0.19 & 0.37 & 0.01 & 0.11 & 2.12 & 4.49 & & & \\
\hline $\mathrm{PO}_{4}{ }^{3-}[\mathrm{mg} / \mathrm{l}]$ & 0.03 & 0.04 & 0.03 & 0.02 & $<0.01$ & $<0.03$ & 0.07 & 0.25 & & & \\
\hline$P$ total $[\mathrm{mg} / \mathrm{l}]$ & \multicolumn{8}{|c|}{ under LOF: $0.10 \mathrm{mg} / \mathrm{l}$} & 0.15 & 0.05 & \\
\hline $\mathrm{DOC}[\mathrm{mg} / \mathrm{l}]$ & 4.17 & 2.47 & 3.95 & 1.94 & 3.38 & 1.61 & 5.83 & 4.87 & & & \\
\hline Ca [mg/l] & 7.83 & 10.00 & 8.16 & 10.5 & 4.25 & 6.23 & 11.20 & 13.8 & 120 & & 30 \\
\hline $\mathrm{Mg}$ [mg/l] & 0.99 & 1.74 & 1.04 & 1.74 & 0.47 & 1.08 & 1.3 & 2.38 & 190 & & 10 \\
\hline chlorophyll A [mg/l] & 4.57 & 67.90 & 3.60 & 5.90 & $<1$ & $<1$ & 10 & 680 & & & \\
\hline \multicolumn{12}{|c|}{$\begin{array}{l}\text { a) Limits of permissible pollution of surface water under the Decree No. 401/2015 Coll. - annual averages } \\
\text { b) Limits of permissible pollution of surface water used for water supply under the Decree No. 401/2015 Coll. - annual averages } \\
\text { c) Limits of permissible pollution of drinking water under the Decree No. 252/2004 Coll., with updates No: 187/2005 Coll., 293/2006 Coll., 83/2014 } \\
\text { Coll., 70/2018 Coll. - the highest acceptable values }\end{array}$} \\
\hline
\end{tabular}




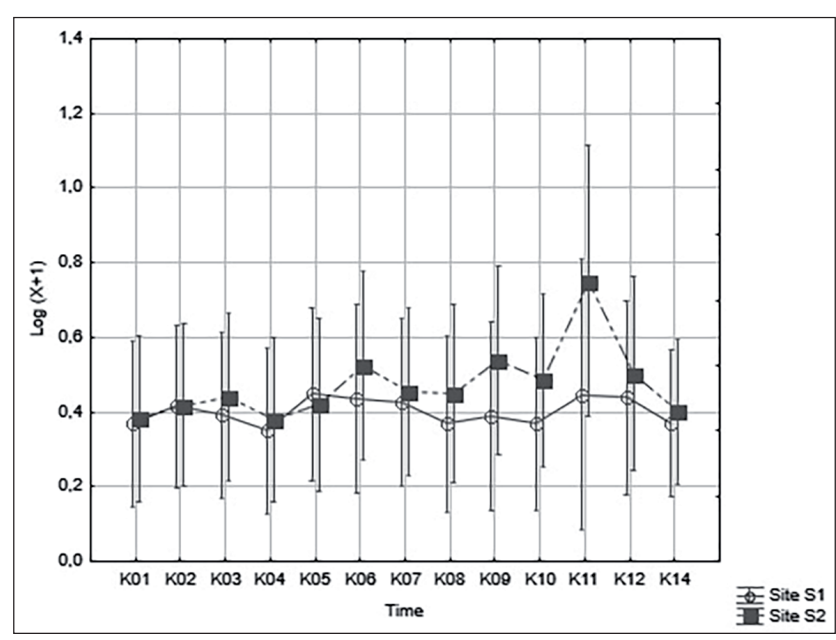

Fig. 4 The quality of the water slightly fluctuated during the season (dates sampled: K01-K14). However, both artificial reservoirs (S1 and S2 sites) showed similar trends. Vertical bars denote 0.95 confidence intervals.

Logarithmic transformation $\log (\mathrm{x}+1)$ was used to standardize some data. Data preparation and visualizations of our results were done in Microsoft Excel.

\section{Results}

\section{Water quality in artificial reservoirs}

The quality of the water in the reservoirs fluctuated during the season. Using Repeated Measurement in Splitplot ANOVA, statistically significant differences between sample dates (ANOVA, $\mathrm{p}<0.001$ ) were found. The first samples $\mathrm{K} 1$ and last samples K14 had similar parameters. They were collected immediately after filling the reservoirs on April 3, 2019 and January 6, 2020, respectively. Values of many of the parameters increased at the end of summer and during autumn. Similar trends were recorded in the upper (S1) and lower (S2) reservoirs. There were no significant differences between sites S1 and S2 $\left(\mathrm{F}_{(12,216)}=1.4256, \mathrm{p}=0.156\right.$; Fig. 4).

During 2019, the $\mathrm{pH}$ values of the water in the upper (S1) reservoir, which is mainly filled from Černohorský Creek, were slightly lower (Table 2, Fig. 5). In this reservoir, the highest $\mathrm{pH}$ value of 8.56 was recorded on July 2, 2019, but it decreased to 7.77 only 14 days later and subsequently fluctuated around 7.5 until the end of 2019. A significant decrease was recorded in sample K14, sampled on January 7, 2020. In the lower reservoir (S2), $\mathrm{pH}$ values increased slightly during the summer and the highest value of 8.97 was recorded on September 3, 2019.

The conductivity increased in both reservoirs during the season (Fig. 6). Slightly higher, but not statistically significant values were recorded in the lower S2 reservoir. The highest values were recorded in the lower S1 reservoir at the end of September and in October 2019.

The nutrients, i.e. nitrogen and phosphate ions, as well as their organic forms and total amounts of these elements, were very low in both reservoirs during 2019 (Table 2). They were under the legal limits determined by the Czech standards on the quality of surface water (CZ Decree No. 401/2015 Coll.) and drinking water (CZ Decree No. 70/2018 Coll.). Concentrations of total phosphorus were below the level of detectability. Also, the concentrations of phosphate ions were very low during the study period (Fig. 7), only higher values were recorded on July 16, 2019. Nearly a ten times higher value of $\mathrm{PO}_{4}{ }^{3-}$ ions than usual were recorded in the lower (S2) reservoir on that date.

Samples from the lower (S2) reservoir had higher nitrate and total nitrogen concentrations throughout the observation period (Fig. 8), however, a statistically

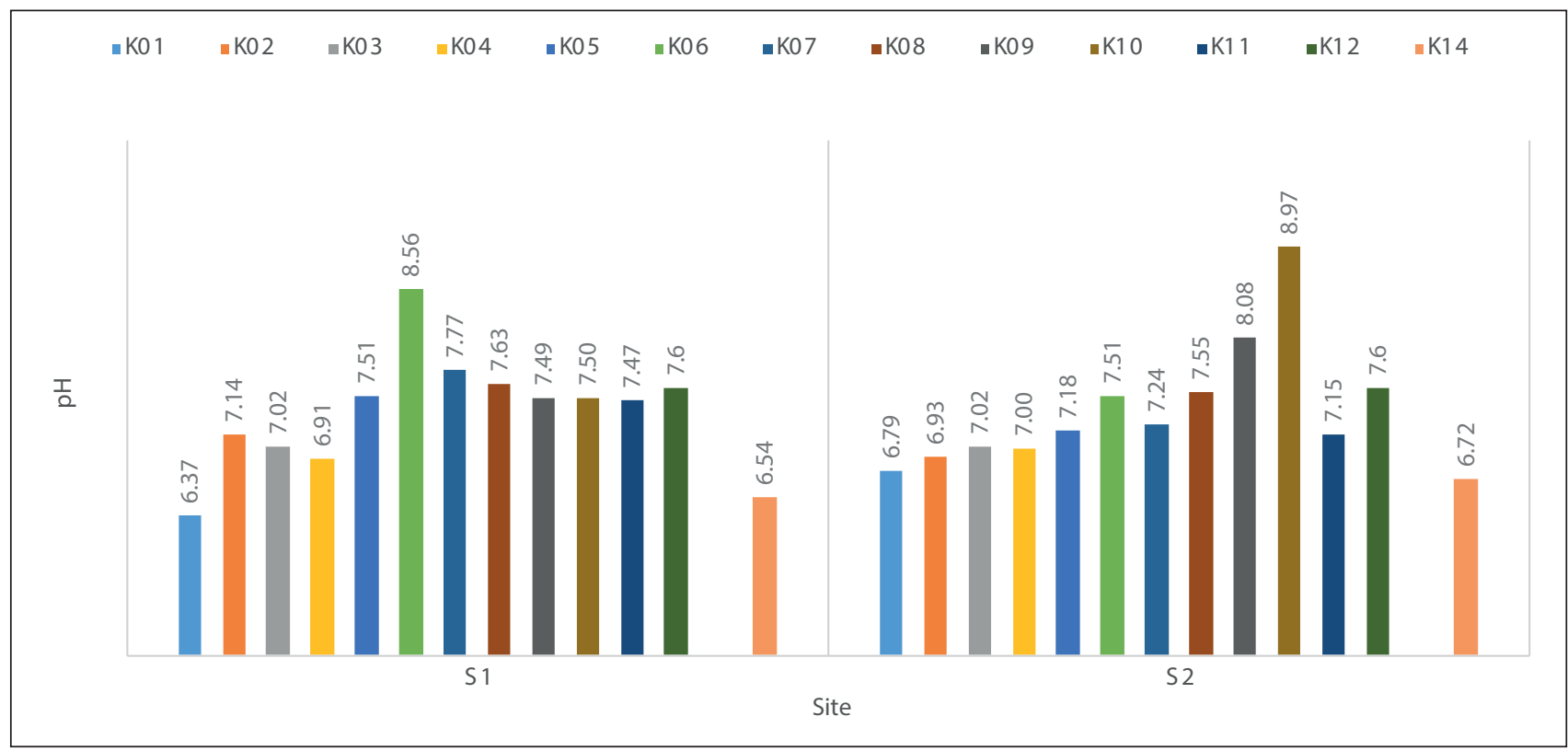

Fig. 5 Seasonal changes in $\mathrm{pH}$ recorded in the upper (S1) and lower (S2) reservoirs. The numbers above the coloured columns are the $\mathrm{pH}$ values of samples K01-K14 (for dates sampled see Table 1). 


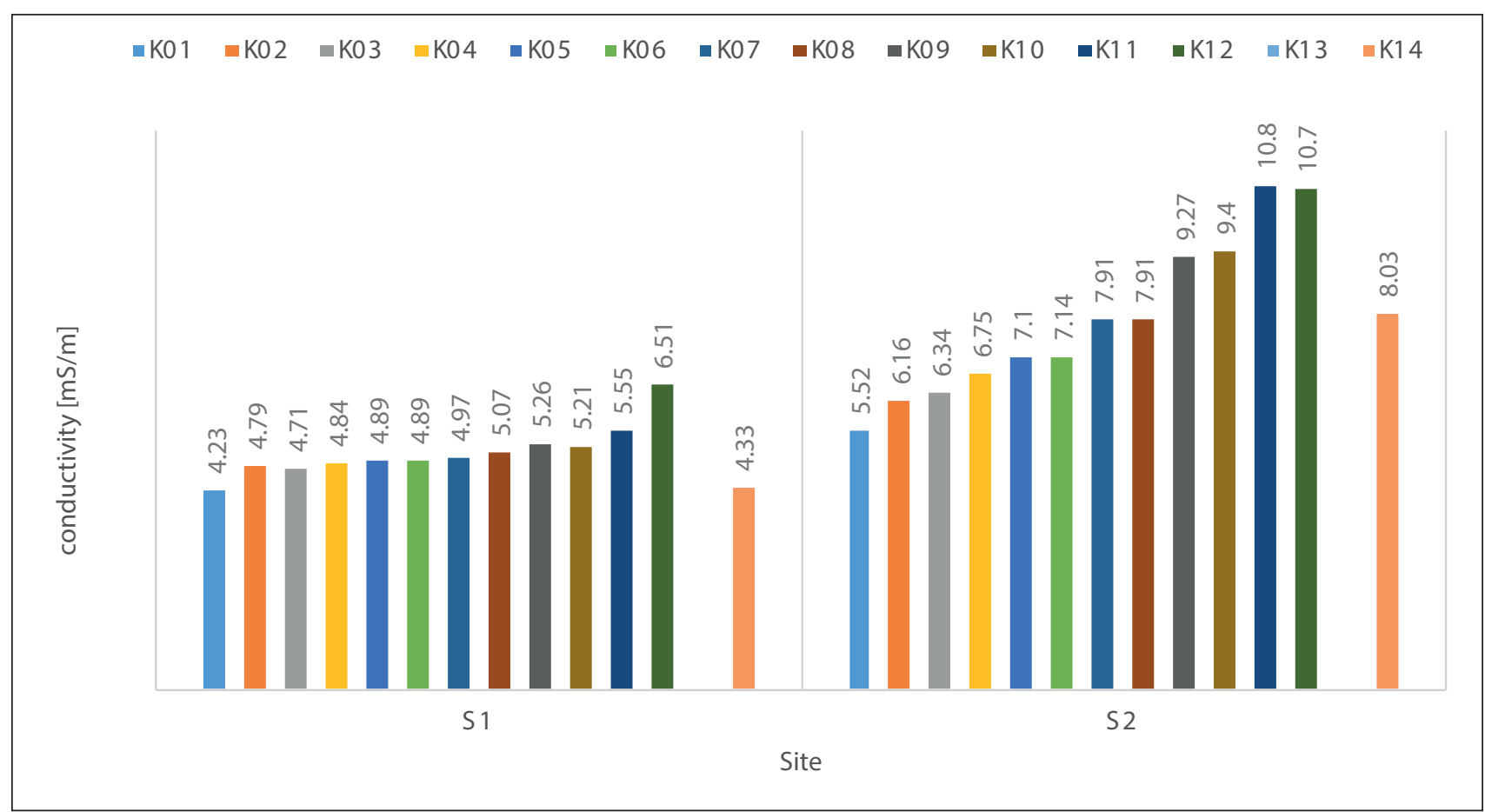

Fig. 6 Seasonal changes in conductivity recorded in the upper (S1) and lower (S2) reservoirs. The numbers above the coloured columns are the conductivity values $[\mathrm{mS} / \mathrm{m}]$ of samples K01-K14 (for dates sampled see Table 1).

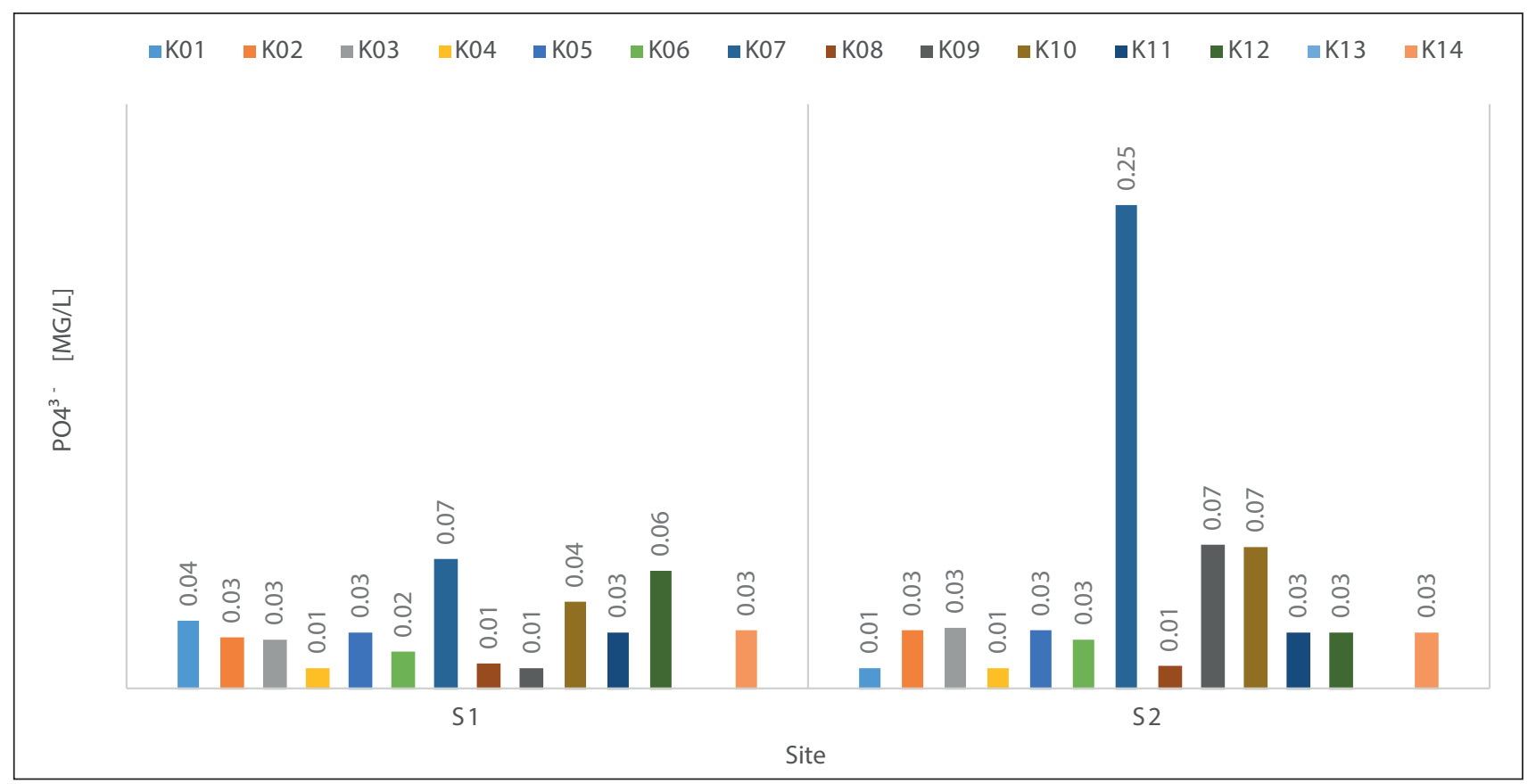

Fig. 7 Seasonal changes in the concentration of phosphate ions $\left(\mathrm{PO}_{4}{ }^{3-}\right)$ recorded in the upper (S1) and lower (S2) reservoirs. The numbers above the coloured columns are the $\mathrm{PO}_{4}{ }^{3-}$ ion concentrations [mg/l] of samples K01-K14 (for dates sampled see Table 1).

significant difference between the upper (S1) and lower (S2) reservoirs was confirmed only for nitrates (ANOVA, $\mathrm{p}<0.001)$. The sample K11 taken from the lower reservoir (S2; sampled on September 29, 2019) contained much higher concentrations of organic and total nitrogen. Also, the concentration of chlorophyll A was very high at that time (Table 3, Fig. 9), which was associated with a high abundance of algae. At the same time, there were also increases in organic and total nitrogen concentrations, but at much lower values, in the upper (S1) reservoir (Fig. 8). Concentrations of nitrates in the lower reservoir decreased during the season and reached its lowest values by the end of September 2019.

The water in the upper (S1) reservoir contained statistically less magnesium and calcium than that in the lower (S2) reservoir (ANOVA, $\mathrm{p}<0.001$; Fig. 10).

\section{Comparison of water quality in reservoirs and small creeks}

Quality of the water in the reservoirs (S1, S2) and particular small creeks (S3-S8) was compared and sta- 


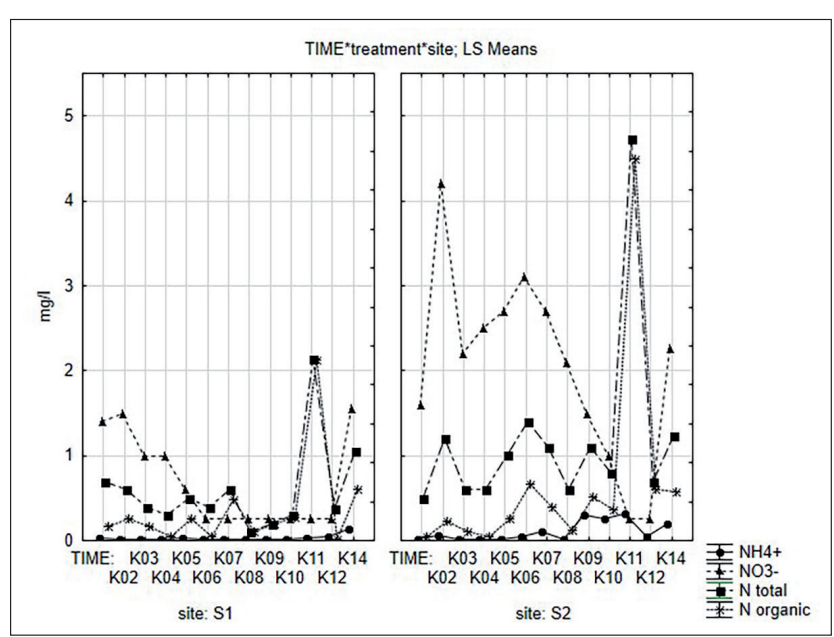

Fig. 8 Seasonal changes in the concentrations of nutrients recorded in the upper (S1) and lower (S2) reservoirs in samples K01-K14 (for dates sampled see Table 1). $\mathrm{NH}_{4}{ }^{+}$- ammonium ions, $\mathrm{NO}_{3}{ }^{-}$- nitrate ions, $\mathrm{N}$ total - total nitrogen, $\mathrm{N}$ organic - organic nitrogen.

tistically significant differences in $\mathrm{pH}$ values (Fig. 11) and conductivity (Fig. 12) were recorded (ANOVA, $\mathrm{p}<0.001)$. The lowest $\mathrm{pH}$ values were repeatedly recorded in samples from the Černohorský Creek (S3, Fig. 11).

Phosphate values, as in reservoirs, were very low in the creeks. In addition to the significantly higher value recorded in sample $\mathrm{K} 07$ from the lower reservoir (site S2, collected on 16 July 2019), a higher concentration of phosphate ions was also recorded in sample K09 from Janský Creek (site S4, collected on 22 August, 2019). Also, other K09 samples, collected from other creeks (S3 and S5-S8) on 22 August, 2019, had slightly higher concentrations of phosphate ions compared to the rest of the season. Total phosphorus values in the reservoirs were lower than the limit of detection.
Statistically significant differences (ANOVA, $\mathrm{p}<0.001$ ) were recorded for nitrate concentrations (Fig. 13). Samples from the upper (S1) reservoir and Černohorský Creek (S3) had much lower concentrations of nitrates than other sites. Concentrations of ammonium ions, organic and total nitrogen were very low in the samples from creeks (S3-S8) and reservoirs (S1, S2) throughout the season and none differed significantly. Only samples K11 collected from reservoirs (S1 and S2) on 29 September, 2019, had higher concentrations of total and organic nitrogen, as mentioned above.

Statistically significant differences (ANOVA, $\mathrm{p}<0.001)$ were recorded between reservoirs and creeks in the concentrations of magnesium (Fig. 14) and calcium (Fig. 15). The highest concentrations of both elements were recorded in samples from Čistá Creek (S8) and the lowest in samples from the Černohorský Creek (S3). The samples from Zelený Creek (S5) also had lower concentrations of magnesium and calcium than the others.

\section{Discussion}

Throughout 2019, water nutrition parameters in the two reservoirs and six creeks were very low and similar to that reported by Hruška (2017) for Labská Dam and several creeks in the Špindlerův Mlýn region. Similar to his results, the concentrations of nutrients we recorded did not exceed the limits of permissible pollution of surface and drinking water defined by Czech legislation (CZ Decree No. 401/2015 Coll., CZ Decree No. 70/2018 Coll.). The upper (S1) reservoir was two thirds full of very clear and nutritionally poor water from the Černohorský Peat Bogs and Janský Creek, respectively, and one third from the

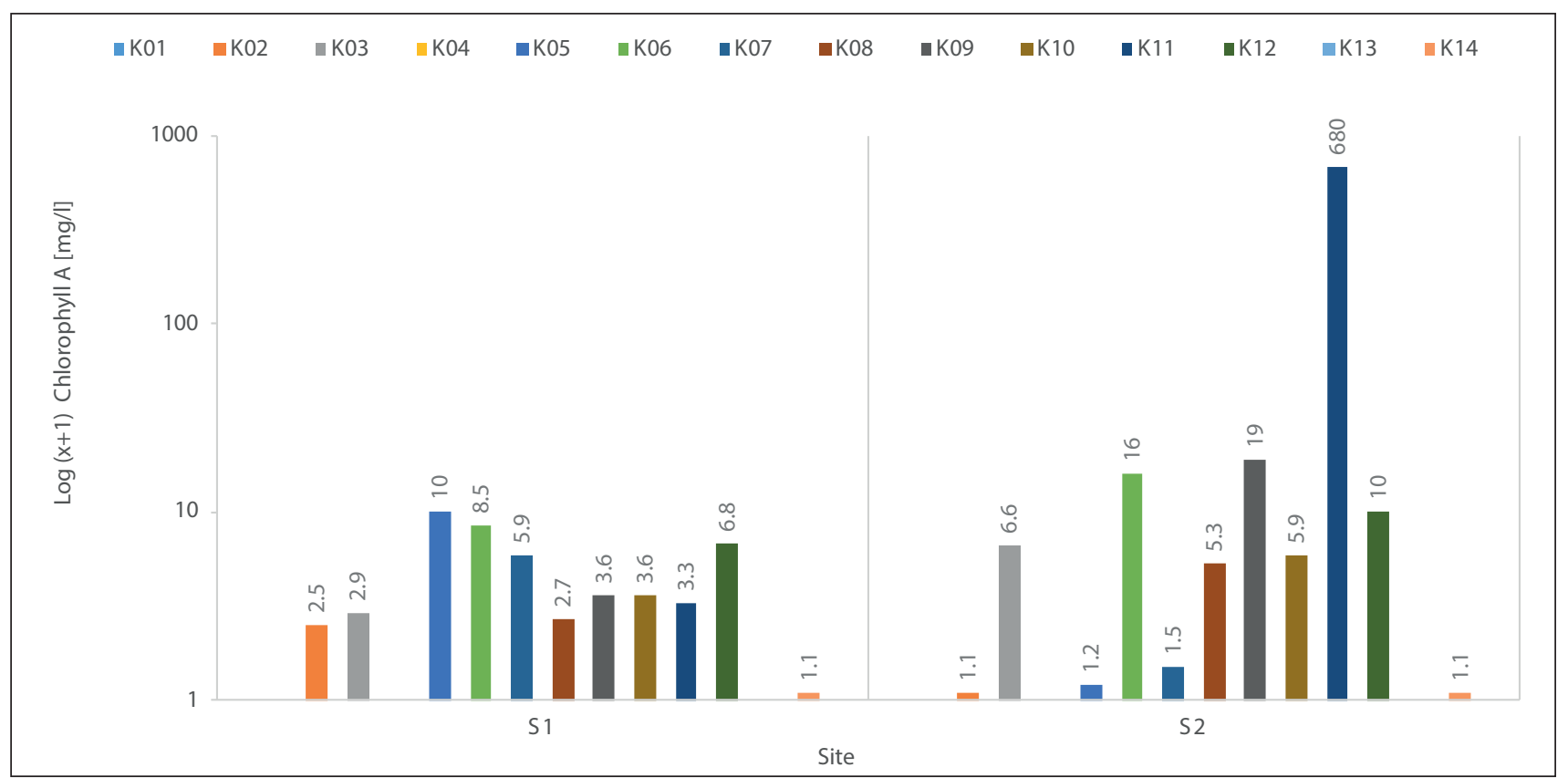

Fig. 9 Seasonal changes in the concentration of chlorophyll A recorded in the upper (S1) and lower (S2) reservoirs. The numbers above the coloured columns are logarithmic scale $\log (x+1)$ chlorophyll A concentrations [mg/l] for samples K01-K14 (for dates sampled see Table 1). 


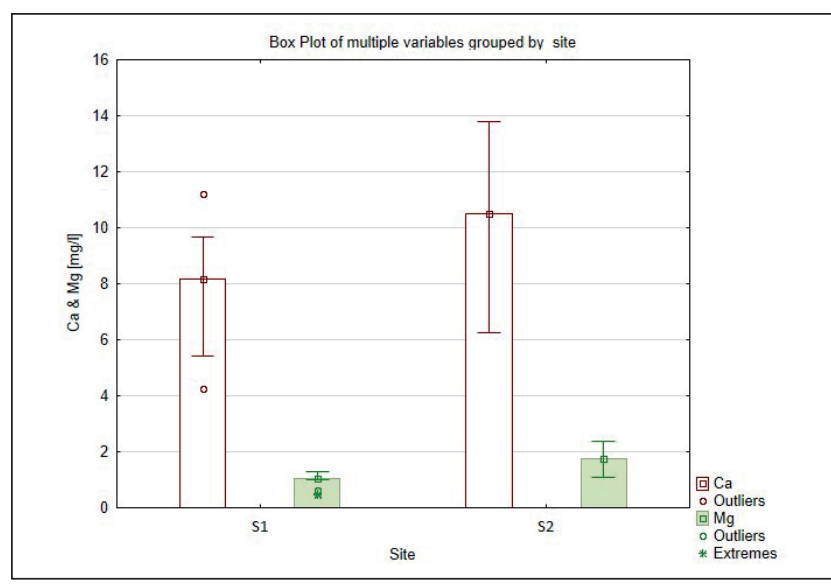

Fig. 10 Concentrations of magnesium (Mg) and calcium (Ca) recorded in samples from the upper (S1) and the lower (S2) reservoirs.

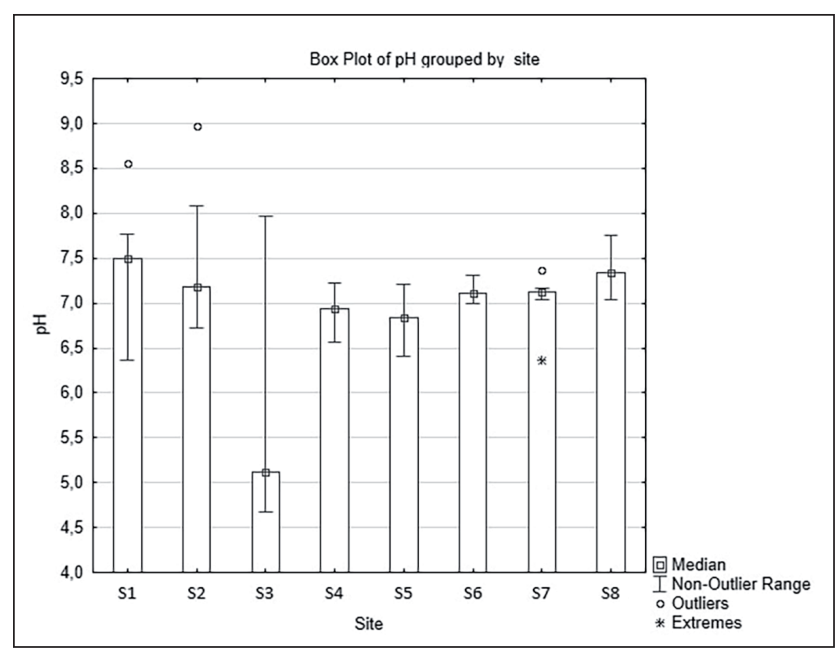

Fig. $11 \mathrm{pH}$ values recorded in samples from two reservoirs (S1, S2) and six creeks (S3-S8).

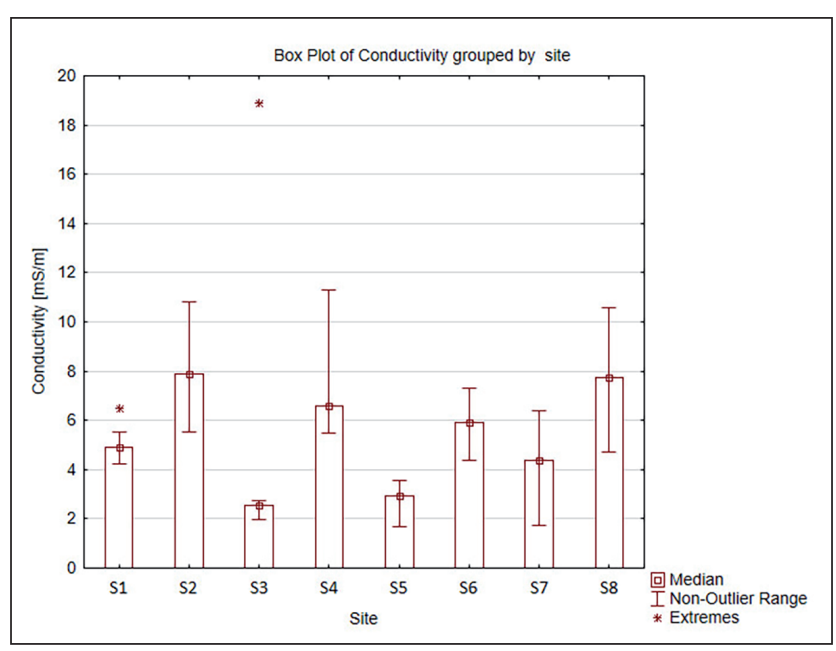

Fig. 12 Conductivity recorded in samples from two reservoirs (S1, S2) and six creeks (S3-S8).

lower reservoir in spring. It then remained the same until November 2019 when production of artificial snow started. The $\mathrm{pH}$ and conductivity of the peaty water in $\mathrm{S} 1$ were lower than recorded in the lower reservoir (S2), which is permanently connected with Janský Creek. Samples from

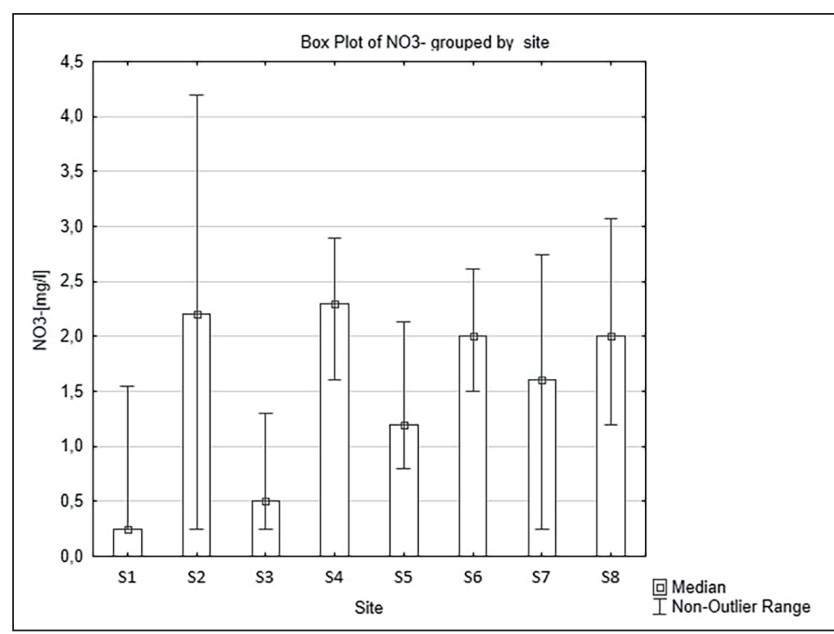

Fig. 13 Concentrations of nitrate ions $\left(\mathrm{NO}_{3}^{-}\right)$recorded in samples from two reservoirs $(\mathrm{S} 1, \mathrm{~S} 2)$ and six creeks (S3-S8).

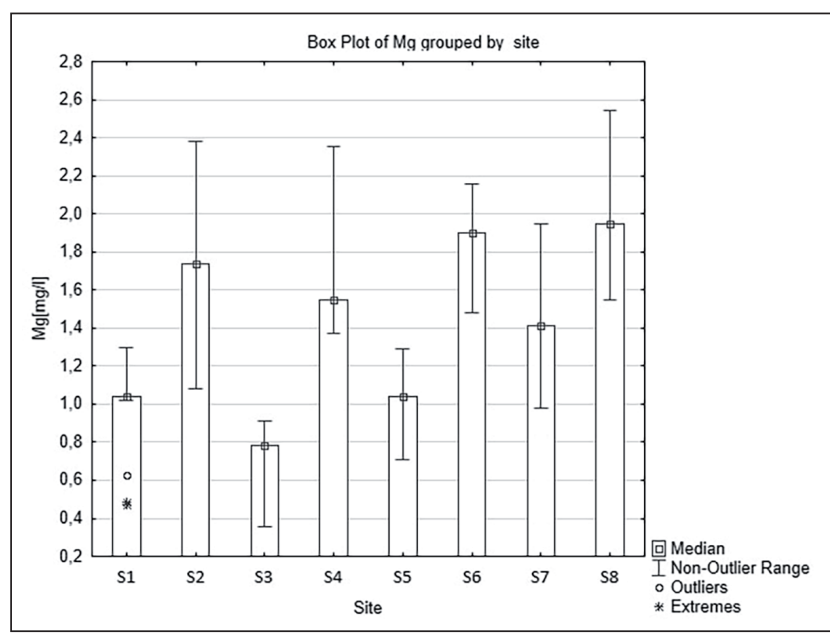

Fig. 14 Concentrations of magnesium $(\mathrm{Mg})$ recorded in samples from two reservoirs $(\mathrm{S} 1, \mathrm{~S} 2)$ and six creeks $(\mathrm{S} 3-\mathrm{S} 8)$.

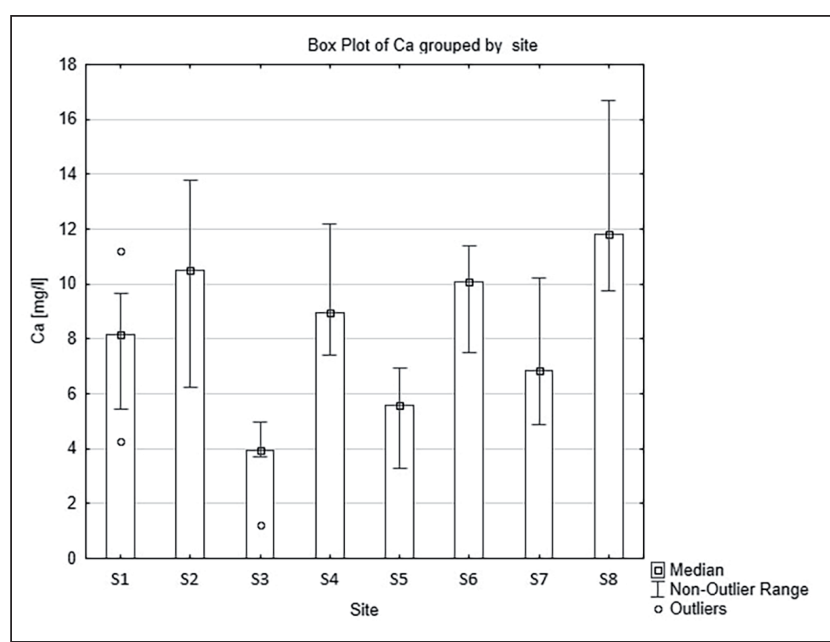

Fig. 15 Concentrations of calcium (Ca) recorded in samples from two reservoirs $(\mathrm{S} 1, \mathrm{~S} 2)$ and six creeks (S3-S8).

S2 had a slightly higher nutrient contents but there were no significant differences between the two reservoirs. Repeated measures analyses showed significant differences between sample dates. Partly water sharing between the lower and upper reservoir (i.e. about one third of the wa- 
ter in the upper reservoir came from the lower one) could explain similar trends in both reservoirs. Some nutrients from the lower reservoir were transferred to the upper reservoir. Concentrations of nutrients increased slightly during summer and the highest values were recorded at the end September. It is likely that natural seasonal dynamics in hydrochemical parameters together with those of water microorganisms (e.g. Kopáček et al. 2011; Fott 2013) account for these seasonal increases in nutrients.

The concentrations of nitrates and phosphate ions, organic forms and total volumes of phosphorus and nitrogen were very low in both reservoirs throughout season. Although low nutrient concentrations were recorded, some fluctuations in nutrient and chlorophyll A concentrations were recorded during summer. Higher concentrations and greater fluctuations were recorded in the lower reservoir (S2). The quality of water in this reservoir may be affected by the flushing of nutrients from around the reservoir or inflow of polluted water from Janský Creek, because samples from this creek (S4) repeatedly had higher concentrations of some nutrients. It is likely that these increases are associated with increases in the occupation of hotels and apartment houses in the small catchment area of Janský Creek above the reservoir.

High values of phosphates were recorded in sample K7 from the lower reservoir (S2; collected on July 16, 2019), when it was nearly ten times higher than the average value. At that time, the catchment of a small un-named creek entering the lower reservoir was landscaped and large amounts of soil moved, which resulted in large amounts of soil and other organic material contaminating the water. Also, high summer temperatures could have resulted in a mixing of the water in this reservoir, which was established in 2006, resulting in some of the phosphate in bottom sediments being circulated. In addition, the large population of brook trout may have eaten most of the invertebrates resulting in a massive increase in phytoplankton. The various factors and their combinations can differ from year to year. These risks can be eliminated or at least significantly reduced by proper water management in the area. A slight increase in phosphates was recorded in summer in the upper reservoir (S1), but this reservoir was recently cleaned so it contains very little sediment. Significantly lower concentrations of magnesium and calcium were recorded in the upper reservoir (S1), which was two-thirds filled with peaty bog water from Černohorský Creek whose source is the Černohorský Peat Bogs. Like bog water this water contains low concentrations of magnesium and calcium (Bourbonniere 2009; Špaček 2017).

Comparing data from reservoirs and several local creeks we found that water from Černohorský Creek (S3) had the lowest $\mathrm{pH}$. This corresponds with results of Špaček (2017), who recognized Černohorský Creek as the most acidic creek in the Úpa River catchment, with $\mathrm{a} \mathrm{pH}_{\min }=4.3$ and $\mathrm{pH}_{\mathrm{avg}}=5.7$. Samples from Černohorský Creek (S3) and the upper reservoir (S1), which is filled from this creek, also had significantly lower concentra- tion of nitrates, magnesium and calcium, than samples from other sites. Samples from all creeks and both reservoirs had very low concentrations of ammonium ions, organic and total nitrogen throughout the season and did not differ significantly. Samples collected from Čistá Creek (S8) had the highest concentrations of magnesium and calcium, which reflects the occurrence erlan, a highly metamorphic limestone, in the area around the source of this creek (https://mapy.geology.cz).

\section{Conclusions and Recommendations}

We can conclude that the contents of nutrients recorded in two reservoirs and six creeks were very low throughout 2019. They did not exceed the limits legally permissible in surface and drinking water. Using water from these reservoirs and creeks for making snow does not result in a significant risk of adding fertiliser to the meadows on ski slopes. This study did not measure the direct effects of artificial snow on grassland, but using water with low concentrations of nutrients is unlikely to increase the fertility or change the species composition of mountain meadows. However, the results of our study cannot exclude that some other aspects of snowmaking can affect mountain meadows.

To eliminate the risks, we recommend: (i) fill reservoirs with water in spring when the runoff water is usually high and of very good quality; (ii) do not add water and avoid disturbing the sediment in the reservoirs in summer; (iii) avoid adding fish, sewage water or other sources of contamination to reservoirs.

To better understand the effect of artificial snow on the ecology of mountain meadows a set of permanent plots should be established and long-term monitoring of vegetation, soil invertebrates and soil chemistry undertaken. Long-term monitoring is essential, because experiences from different locations (e.g. Wipf 2002) show that significant changes occur over long periods, especially in ski resorts above the tree line, where natural alpine meadows occur. Monitored plots should be on ski slopes with and without artificial snow.

\section{Acknowledgements}

We thank the following institutions and persons: P. Hynek and Ski Resort staff for initiating this research and providing logistical support. LABTECH Brno Ldt. Hygienic Laboratories Klatovy for chemical analyses and A. F. G. Dixon for revising the language. This work was supported by the Global Change Research Institute of the Czech Academy of Sciences.

\section{REFERENCES}

AHS (2019) České hory za sebou mají vydařenou sezónu. TZ 11. 4. 2019; Available from: https://www.ahscr.cz/-2/tiskove-zpravy/. 
Anonymous (2012) STATISTICA, v. 12, StatSoft, Inc, Tulsa, OK, USA; Available from: http://www.statsoft.com.

Bourbonniere RA (2009) Review of Water Chemistry Research in Natural and Disturbed Peatlands. Can Water Resour J/Revue canadienne des ressources hydriques. 34: 393-414.

Breiling M, Charamza P (1999) The impact of global warming on winter tourism and skiing: a regionalised model for Austrian snow conditions. Reg Environ Change 1: 4-14.

Elsasser H, Bürki R (2002) Climate change as a threat to tourism in the Alps. Clim Res 20: 253-257.

Flousek J (2016) Vliv lyžování na horskou přírodu: shrnutí současných poznatků a stav v Krkonoších. Opera Corcontica 53: $15-60$.

Fott J (ed) (2013) Limnology of Mountain Lakes. Springer Science and Business Media.

Freppaz M, Filippa G, Corti G, Cocco S, Williams MW, Zanini E (2013) Soil properties on ski-runs. In: Rixen C, Rolando A (eds) The impacts of skiing and related winter recreational activities on mountain environments. Bentham Science Publishers Bussum, pp 45-64.

Fuksa JK (2016) Umělé zasněžování - vliv na vodní toky a ekosystémy. Newsletter Adaptace měst na klimatickou změnu 5/2016, Sbor. př́sp. konf. Tvoříme klima pro budoucnost, Liberec, 26.-27. 1. 2016: 22-24.

Hruška J (2017) Propojení areálů Špindlerův Mlýn: Stanovení změny překročení kritických zátěží dusíku použitím povrchové vody $\mathrm{z}$ přehrady Labská k umělému zasněžování. [Interconnection of ski resorts of Špindlerův Mlýn region: Determination of the change of critical nitrogen loads exceeded by the use of surface water from the Labská Dam for technical snow]. Global Change Research Institute CAS, Brno, Czech Republic; Available from: https://portal.cenia.cz/eiasea/detail/EIA_HKK906.

Hruška J, Hošek J, Hofmeise, J, Čížek L (2017) Kritické zátěže síry a dusíku pro lesní ekosystémy NP Krkonoše a jejich překročení atmosférickou depozicí v roce 2016. Ms. depon In: Správa KRNAP, Vrchlabí.

Jones HG, Devarennes G (1995) The chemistry of artificial snow and its influence on the germination of mountain flora. IAHS Publications-Series of Proceedings and Reports 228: 355-362.

Kammer PM (2002) Floristic changes in subalpine grasslands after 22 years of artificial snowing. J Nat Conserv 10: 109-123.

Kocková J (2011) Srovnání vegetace sjezdových tratí s umělým a prrírodním sněhem v CHKO Bílé Karpaty a v CHKO Beskydy. [Comparison of vegetation on ski slopes with artificial or natural snow in CHKO Bílé Karpaty and CHKO Beskydy.
Mgr. Thesis, in Czech]. Faculty of Sciences, University of South Bohemia, České Budějovice, Czech Republic.

Koenig U, Abegg B (1997) Impacts of climate change on winter tourism in the Swiss Alps. J Sustain Tour 5: 46-58.

Kopáček J, Hejzlar J, Vrba J, Stuchlík E (2011) Phosphorus loading of mountain lakes: Terrestrial export and atmospheric deposition. Limnol Oceanogr 54: 1343-1354.

Negro M, Isaia M, Palestrini C, Rolando A (2009) The impact of forest ski-pistes on diversity of ground-dwelling arthropods and small mammals in the Alps. Biodivers Conserv 18: 2799-2821.

Negro M, Isaia M, Palestrini C, Schoenhofer A, Rolando A (2010) The impact of high-altitude ski pistes on ground-dwelling arthropods in the Alps. Biodivers Conserv 19: 1853-1870.

Špaček J (2017) Vyhodnocení acidifikace a aktuálního ekologického stavu vodních toků. In: Beranová et al. (eds) Aktuální stav lesních a vodních ekosystémů na území evropsky významné lokality Krkonoše. Výstup projektu č. EHP-CZ02OV-1-023-2015. Správa KRNAP. Vrchlabí. pp 35-44.

Štursa J (2007) Ekologické aspekty sjezdového lyžování v Krkonoších. In: Štursa J, Knapik R (eds) Geoekologické problémy Krkonoš. Sborn Mez Věd Konf, říjen 2006, Svoboda n. Úpou. Opera Corcontica 44: 603-616.

Thiel D, Jenni-Eiermann S, Braunisch V, Palme R, Jenni L (2008) Ski tourism affects habitat use and evokes a physiological stress response in capercaillie Tetrao urogallus: a new methodological approach. J Appl Ecol 45: 845-853.

Treml P (2019) Dopad technického zasněžování na toky v Krkonoších. VTEI 61: 20-30.

Treml P, Hanel M, Kašpárek L, Novický O, Březina S (2012) Vliv odběrů vody pro technické zasněžování na odtokovou výšku hlavních toků v Krkonoších. Opera Corcontica 49: 73-87.

Vanat L (2019) 2019 International Report on Snow \& Mountain Tourism. Overview of the key industry figures for ski resorts and mountain tourism. Geneve [online] [cit. 4. 4. 2020]. Available from: http://www.vanat.ch/tarif-WR-data-2019.pdf.

Wipf S, Rixen C, Fischer M, Schmid B, Stoeckli V (2005) Effect of ski piste preparation on alpine vegetation. J Appl Ecol 42: 306-316.

Zeidler M, Duchoslav M, Banaš M (2016) How alpine heathlands response to the snow cover change on the ski slope? Long-lasting ski slope impact case study from the Hrubý Jeseník Mts. (Central Europe). Acta Soc Bot Pol 85: 1-13.

Zeitler A, Glanzer U (1998) Skiing and grouse in the Bavarian Alps. Grouse News 15: 8-12. 